\title{
Dark memories in the provincial worlds of Ingmar Bergman's Fanny and Alexander and Federico Fellini's Amarcord
}

In a late interview, Ingmar Bergman recalled his close friend and colleague Federico Fellini: "I loved him both as a director and as a person, and I still watch his films [...] above all, that childhood depiction".[1] Perhaps Bergman appreciated Amarcord (1973) because of its affinities with his own depiction of childhood in Fanny and Alexander $(1982 / 1983)$. In this brief essay, I will explore one of the similarities between these films, namely the discrete insertion of a threatening power into an otherwise rather idyllic and nostalgic world.

Bergman and Fellini, born in 1917 and 1920, respectively, belonged to the same generation and made personal films about their childhood universe at around the same time; Fellini with Amarcord in 1973 and Bergman with Fanny and Alexander in 1982. These films would be their last great audience successes; both would win the Academy Award for best foreign language film, and both met with significant critical acclaim.[2] Premiering at Christmas, each film offered cross-generation spectacles, enriched with occasional reminiscences of their earlier, somewhat less accessible, art cinema filmmaking. Within these popular childhood worlds, there are moments of darkness, also stemming from the directors' childhoods. My interest here is to discern similarities in how the somewhat aging directors chose to use disturbing memories and insert fragments of them into their films.

Fanny and Alexander is set in 1907, ten years before Bergman himself was born, whereas Fellini's film, set sometime between 1933 and 1937, better coincides with the director's own adolescence.[3] Although it is generally assumed that the main characters, the 10-year old Alexander and the roughly 14-year old Titta, are the directors' alter

[1] J. Aghed, När Bergman går på bio, Sydsvenska dagbladet, 31 July 2007, <http://www.sydsvenskan.se/ kultur-nojen/nar-bergman-gar-pa-bio-1/> [accessed 31 May 2013].

Fellini appreciated Bergman and his films just as much. For example, asked to comment on Sight and Sound's list of best films, he wondered: "Ma come si può fare una classifica del genere senza inserirvi almeno un film di Bergman?” In F. Fellini, Fellini. Raccontando di me. Conversazioni con Costanzo vol. XII/no. 21

Poznań 2013

ISSN 1731-450x 
egos, it is quite clear that these films are not autobiographical in any traditional sense. [4] Rather, both films offer rich depictions of a multitude of persons, places and events, where memories of the past have been reformulated and complemented with a high degree of imagination.

Bergman's film is more confined to the home and the family sphere than Fellini's. Bergman grew up in Stockholm and was only a temporary visitor to his grandmother's home in the small city of Uppsala, depicted in the film. The recollections of Uppsala inspired him from the early stages of writing. In Images he writes:

From the very beginning one can see that with Fanny and Alexander I have landed in the world of my childhood. Here is the university town and Grandmother's house with the old cook; here is the Jew who lived out back; and here is the school. I am already in the place and beginning to roam around in the familiar environment.[5]

In a similar way, but with a horizon that extends well beyond the home and family, Fellini revisits his childhood and adolescence in Rimini, where he lived until he had finished school and in 1939 left his childhood town for Rome.

The two directors structured their memories differently. In the end, Bergman settled for a straightforward - albeit very long, almost epic - chronological story, whereas Fellini renounced an overarching storyline and instead orchestrated a large array of freestanding episodes. Tullio Kezich's suggestion that Amarcord is structured as a series of jokes is to the point:

[...] it tells an infinite number of small-town stories, each with a beginning and an end, the content is almost always mockingly presented and with a tendency towards the fantastic. Structurally, Amarcord is an embellished chattering of memories, made for its own pleasure, as well as for the audience's amusement.[6]

When Bergman writes about his work with Fanny and Alexander, quoting recollections already formulated in his autobiography, he could equally well, or perhaps even more so, have been writing about Amarcord. Bergman's childhood was, he recalls, full of "strange occurrences, unexpected sights, and magical moments", and when he compares his recollections with film sequences, these sequences were

[4] For example, Fellini named the protagonist Titta after his best friend (Luigi Benzi, nicknamed Titta), with whom he shared many experiences.

[5] I. Bergman, Images. My Life in film, trans. M. Ruuth, Arcade Publishing, London 1994, p. 366. [6] T. Kezich, op. cit., pp. 302-303. My translation. See also: "The succession of scenes in Amarcord has the fluid rhythm of the seasons that punctuate the life of the town. [...] Extras (the lawyer, the distracted motorcyclist), apparitions (the Rex, the peacock), dreamlike evocations (the meeting with the prince) are disengaged at the right moment, obeying a musical rhythm. All is natural and necessary in this popular fresco in which no one sequence is more successful than another." A. Tassone, "From Romagna to Rome: The Voyage of a Visionary Chronicler (Roma and Amarcord)," in: Federico Fellini: Essays in Criticism, ed. P. Bondanella, Oxford University Press, Oxford 1978, pp. 261-288, pp. 284-285. 
"rarely episodes with a particular meaning, short or long, randomly shot films with no point. The prerogative of childhood: to move without any constraints between magic and oatmeal porridge, between limitless terror and bursting joy" before he concludes that for him "it was difficult to differentiate between fantasies and what was considered to be real." [7] This blending and blurring of memory, imagination and filmmaking is evident in both films, and also described in a similar way by Fellini:

How do you refer to things that really exist? I feel more at ease when I'm inventing. The real Rimini, where I lived during my childhood and adolescence, is confused with another, imagined, recreated, reconstructed in my films made at Cinecittà or in Viterbo and Ostia. The two memories are superimposed and I am no longer able to differentiate between them.[8]

Although both filmmakers move beyond actual events and into the realm of fantasy, it is also clear that they have retained very precise recollections of their early years. Kezich asserts that "Federico [...] has memorized even the nuances of feelings, language, habits and tensions from that household [his friend Tittas] forty years earlier. Regarding Titta, the family scenes of the film are an exact reproduction of what was said and done in his home, as if Federico had had a recording device during those years", [9] whereas Bergman maintained that "if I am calm and just about to fall asleep, I can go from room to room and see every detail, know and feel it. In the quietness of Grandmother's home, my senses opened and decided to keep all this for ever and ever." [10] These vivid memories can be sensed, both regarding thematic richness and in the degree of detail in settings - granting the films authenticity, in spite of their obvious fictionalizations.

As Fellini and Bergman move beyond autobiography and into fantasy, they simultaneously make their stories more universal. Kezich notes that Fellini "never miss[es] an opportunity to repeat that his province [Rimini] is a metaphysical one, possible to transfer, with minor adjustments, to any time and latitude",[11] whereas Birgitta Steene has suggested that "Bergman leaned on Hoffmann (and Dickens) to transcend the private basis of his subject matter. [...] no doubt because Bergman wanted to depict the milieu as a fictional locus rather than a geographic spot that had references to his own life."[12] To judge from the reception of the films, this universalization of their recollections seems to have been utterly successful.

[7] I. Bergman, Bilder, Norstedt, Stockholm 1990, p. 380. My translation.

[8] F. Fellini, Fellini. Raccontando di me, op. cit., p. 14. My translation. "Invented" was the word said during the interview, but later adjusted to "imagined" by Fellini. Ibidem, p. 28.

[9] T. Kezich, op. cit., pp. 301-302. My translation.
[10] I. Bergman, The Magic Lantern. An Autobiography, trans. J. Tate, H. Hamilton, London 1988, p. 20.

[11] T. Kezich, op. cit., p. 302. My translation.

[12] B. Steene, “'Doing the alexander': On Christmas motifs in Bergman's Fanny and Alexander", Journal of Scandinavian Cinema 2013, vol. 3, no. 3 [forthcoming]. 
Fellini points to something that is essential for both films, regarding their foundation in individual memories and lived experience, as well as their transformation into stories that are accessible and may be appropriated by many others:

I think that when one talks about things he knows, and speaks of himself,
and talks about his family, his village [...] I think that his words are always
ones that everyone can understand, everyone can relate to. It seems to me
that the characters in Amarcord, the characters of this small village, es-
pecially because they are so confined to that village, and that village is
a village that I knew very well, and those characters, invented or known,
in any case, I have known or invented them very well, suddenly they
belong not only to you, but also to everyone else.[13] However, precisely no matter how precisely this is precisely captured by Fellini, it does not say anything about what memories are chosen for his film, and how they are recounted.

\section{Authoritarian institutions}

Within the films' fascinating blend of events and emotions ranging from joyous celebrations, and magic stories, to sadness over parents' deaths - I want to focus on the films' incorporation of quite bitter memories of authoritarian institutions - the directors' memories of Fascism and religion - these institutions' rules and coercion and their interfering with peoples' lives. That these memories originate in the directors' childhood is clear. Bondanella observes that "Fellini's distaste for authoritarian institutions can be traced back to his childhood", [14] and Bergman's autobiography The Magic Lantern reveals a similar aversion towards the strict regime of his childhood home and, in particular, his authoritarian father, a Lutheran vicar. Although coercion in the films is exercised by individuals, Bergman and Fellini also place responsibility on institutions, and both sense frightening affinities between religious institutions and the inter-war period's growing influence of Nazi/Fascist movements. Bergman, who writes about his (far too) long-lasting admiration for Hitler in his autobiography, describes the authoritarian religiousness in his family and suggests that this also influenced the family's uncritical stance towards Nazism:

Most of our upbringing was based on such concepts as sin, confession, punishment, forgiveness and grace, concrete factors in relationships between children and parents and God. There was an innate logic in all this which we accepted and thought we understood. This fact may well have contributed to our astonishing acceptance of Nazism.[15]

[13] T. Kezich, op. cit., p. 305. See also A. Tassone about the film's universal appeal: "far from withdrawing into himself, into the 'meanderings of his memory,' knew how to give to his compatriots the most faithful and compelling portrait of their childhood?" (op. cit., p. 288).
[14] P. Bondanella, op. cit., p. 119.

[15] I. Bergman, The Magic Lantern, op. cit., pp. 7-8. Bergman also highlights the influence of a pediatrician, who lent his parents support for their strictness. 
Fellini, concerned about enduring Fascist tendencies in Italian society, thought that Fascism could rise to power so easily because the Catholic Church had already established a mentality of non-individual responsibility which aided Fascism's growth: "And it seems to me that, even before Fascism, the responsibility for this chronic failure to develop, this remaining at an infantile stage, lies with the Catholic Church." [16]

How, then, are the experiences and attitudes of Bergman and Fellini incorporated into the childhood universes of Fanny and Alexander and Amarcord? I will primarily look at two sequences in which Alexander and Titta's father are interrogated and castigated by representatives of authoritarian institutions.

Fellini considers the sequences with the Fascist rally in the middle of the film to be of central importance. They begin with the arrival of an Achille Starace-equivalent Fascist leader at Rimini, which is followed by a parade and a sequence when a gramophone placed in the church tower, begins playing the socialist anthem "The Internationale." The device is shot up down by the Fascists, thus silencing an oppositional voice. The series ends with a painful scene with Titta's father.

Titta's father had stayed at home during the Fascist manifestation - locked up by his wife, who would not allow him to go anywhere close to the Fascists. In the middle of the night, two uniformed men take Titta's father to an office for interrogation. When he denies having had anything to do with the gramophone, or any other anti-Fascist propaganda, he is asked to drink to the victory of the Fascists. Reluctantly sniffing at the drink offered, he realizes that it is castor oil - used by Italian Fascists (and others) for intimidation and punishment, due to its repugnant taste and strong diarrhea-inducing effects. When Titta's father refuses and asks why he should have to drink this (why he should be punished) he is force-fed at least two full glasses of the castor oil before the scene ends with a cut to Titta's mother worryingly waiting outside their home. In the film, this scene is exceptional with its serious tone and its direct political coercion.

In an essay about his Rimini memories, Fellini recounts his suspicion of a similar experience relating to his father. He underlines both the atmosphere of concealment, suspicion and threat as well as the close connections between the Church and the Fascists:

Religion was always something terrorizing. During that period, apart from religion, fascists also appeared. I believe that one of them had beaten my father. I suspected some ugly faces which used to be in the bar dressed in black shirts. My father hid everything to me. Whenever discussions touched upon certain topics, he exchanged meaningful glances with my

[16] F. Fellini, "Il fascismo dentro di noi, Intervista di Valerio Riva," in: Il film 'Amarcord' di Federico Fellini,

\section{Castor oil and carpet beater}

ed. G. Angelucci and L. Betti, Cappelli, Bologna, 1974, p. 103. 
mother, in order not to involve me. My confusion grew the day I saw those suspected ugly faces singing in the church, together with the archpriest.[17]

Bergman's skepticism towards various aspects of religion is embodied by the Bishop, who marries Fanny and Alexander's mother, thus becoming their stepfather. Alexander is the first to recognize the coldness of the Bishop's authority, and he unfailingly seeks to resist it. In what is probably the most terrifying sequence of the film, Alexander suffers the consequences of having made up a story about how the Bishop provoked the drowning of his first wife and their two daughters. When a maid reveals the defaming tale to the Bishop, Alexander is questioned, forced to confess, beaten with a carpet beater and locked up in the attic - being thoroughly humiliated throughout the process.

The events and atmosphere at the Bishop's house are more related to Bergman's memories of his parents and childhood in Stockholm than to his pleasant recollections of his Grandmother and her home in Uppsala - depicted in the film's Ekdahl residence scenes. In his autobiography, Bergman remembers another fantasy story (also mentioned in the film) he had told a friend in school, namely that his parents "had sold him to Schumann's Circus", whereupon his parents followed advice from the family pediatrician who "had emphasized how important it was for a child to learn at an early stage to differentiate between fantasy and reality. As they were now faced with an insolent and flagrant lie, it had to be punished accordingly." [18] Bergman also details the varieties of punishments administered: "punishments were something self-evident, never questioned. They could be swift and simple [...] but they could also be extremely sophisticated, refined through generations." In severe cases, for a lie such as the one in Fanny and Alexander, this would mean that after interrogation and confessions "the carpet beater was fetched [and when] the strokes had been administered, you had to kiss Father's hand". [19]

The two scenes, and the memories they reflect, offer frightening examples of distorted uses of power. Two ordinary persons are humiliated and castigated for something they had not done, or at least something that had not harmed anyone. Rather, they were merely resisting the ideals and ambitions of authoritative institutions. For this they were intimidated, broken down, with the wishful but naïve thought that they would be brought to conformity.

The Bishop as well as the Fascists are confident that they are right - representing, they would maintain, timeless values - and they fail to understand why anyone would not share their convictions. After punishing Titta's father, one of the Fascists says that "What saddens us is this obstinacy in not wanting to understand that fascism wants

[17] F. Fellini, "Il mio paese," in: Il film 'Amarcord'di Federico Fellini, op. cit., pp. 74-75. My translation.

[18] I. Bergman, The Magic Lantern, op. cit., p. 11.
[19] Ibidem, p. 8 
to give them back their dignity", a view echoed by the Bishop when he congratulates Alexander for having won a great victory over himself when he admitted his lie and asked the Bishop for forgiveness. It appears that both the Bishop and the Fascist sincerely meant what they said. Still, few viewers would regard this as something else than expressions of authoritarian institutions failing to accept any diverging opinions or ideologies. Their ostensibly emphatic words sound hollow. Just like, according to Bergman and Fellini, the authority they depend on.

Like Titta's father, Alexander was also presented with castor oil as punishment as an alternative to the carpet beater and to being locked up in a dark and cold cupboard. Alexander chooses the carpet beater. Foregrounding the physical violence he is subjected to - more so than what the castor oil or cupboard would have done - Alexander (and Bergman) accentuates the austere consequences of the Bishop's regime. Fellini seems to have chosen a more reconciling approach; instead of staging the suspected beating of his father he recalled from his childhood he chooses castor oil. In addition, Fellini ends the sequence on a humorous note; as Titta sees his father bathing to get rid of the odour, he does not stay to learn what happened, but instead rather light-heartedly runs off, laughing at how bad his father smells.[20] As Bondanella observes regarding this relative mildness towards the tormentors, "Fellini is not even able to feel hatred towards the Fascists, he only represents them as clowns, just slightly worse than the rest." [21] In this respect, Bergman is much clearer in his critique; the Bishop is certainly no clown. However, it may well be that Bergman's more melodramatic approach, throughout Fanny and Alexander, in the end closes off more critical thoughts about authoritarian institutions than Fellini's disjointed observations.

The authority of the Bishop and the Fascists maltreating Titta's father, and the restraints they impose on others, should be justified. Instead, throughout the films, the dominant institutions and their ideologies are questioned, implying that these individuals' authority is not valid. Here, I will only briefly mention two similar and almost embarrassingly obvious examples of how these institutions are deconstructed: the scenes with the phony faces of the Duce and of God.

[20] Also noted by, for example, Dorothee Bonnigal, "Fellini's Amarcord: Variations on the Libidinal Limbo of Adolescence," in: Federico Fellini. Contemporary perspectives, ed. F. Burke and M.R. Waller, University of Toronto Press, Toronto 2002, pp. 137-154, p. 143. Interestingly, Bonnigal's perspective, where she notes that "Flatulence, castor oil, excrement: adolescent weapons at the service of an adolescent world. The circumscription of the narrative structure within the vicious (and often hilarious) snare of an adolescent perspective not only connects the personal and political spheres, but equates them in a devastating look at fascist Italy" resembles Koskinen and Rohdin's analysis of how "religion and Christianity throughout the film is associated with blasphemy and faeces." Both find childish strategies of resistance used against authorities in these films. See M. Koskinen, and M. Rohdin, op. cit., p. 202. My translation. [21] T. Kezich, op. cit., p. 302. My translation. 
As part of the heavily satirized Fascist parade and manifestation in Amarcord, the Duce's face, a gigantic construction of thousands of red and white flowers, is raised in front of the enthusiastic crowd. The Duce's face speaks and he even joins a young couple in matrimony - at least in the fantasy of the young groom, and to the cheering of all on-lookers. Fellini neatly illustrates the authority, influence and performativity the citizens grant the Duce (the face is also seen to 'stand behind' the fascists as they 'kill' the gramophone, signaling an omnipresent influence), but he equally clearly shows that what they worship is actually only an idol, a construction, which can only rise, speak and perform with the help of marionette operators pulling the threads, and with the imagination of its blind followers. [22]

In Fanny and Alexander, the young protagonist has just been saved from the Bishop's home by Isak, a friend of the Ekdahl family, when he faces a construction of power similar to the one in Amarcord. During the night, Alexander gets lost in Isak's home, hears something, and is told that it is God who stands there, behind a door, talking to him. Alexander is scared. The voice says that those who see the face of God will die, the door opens, a gigantic foot steps into the room, and soon Alexander can see God's face. Instead of dying, however, this God is revealed to be an illusion. A marionette animator living at Isak's appears, and it becomes clear that he was the one speaking and working a marionette God.

Just as in Fellini's film, a constructed idol is capable of casting a spell on their on-lookers. At least momentarily, people in these films are duped, whereas viewers of the films would discern that they were not at all dealing with anything divine, or anything else worthy of their respect. Such is the power of their beliefs. Fellini is concerned about this influence, and what he considers to be "clownish conditioning, theatrical, childish, the subjection to a puppet-like power, to a ridiculous myth". [23] In Fanny and Alexander and Amarcord, this puppetlike power, the marionette God and the Duce figure - i.e. the higher level of authority behind the Bishop and the Fascists - are deconstructed as phony, as constructions created and governed by humans. Consequently, authoritarian institutions are undermined, and there appears to be reasons, and possibilities, to resist them and their power.

Little worlds

To conclude, I want to suggest that this authoritarian-critical discourse, however present in select scenes, within the wider framework of the films is, in the end, given a subordinate position. When Alexander's uncle, Gustaf Adolf Ekdahl, towards the end of Fanny and

[22] As Bondanella points out, the appearance of Rex - the ocean liner that served as a prestige example of Fascist engineering - is a similar example of how people sought out opportunities to be fooled by illusive appearances: "After its passing, the townspeople fail to notice that the Rex is merely a flat façade that falls back into the ocean, revealing its status as both a movie prop and the embodiment of a false and mystifying image manipulated by an evil regime." P. Bondanella, op. cit., p. 132.

[23] F. Fellini, "Il fascismo dentro di noi, Intervista di Valerio Riva," op. cit., p. 101. My translation. 
Alexander holds a longer speech, he positions his large family within a much wider and more sinister context, maintaining that "The world is a den of thieves and night is falling. Evil breaks its chains and prowls the world like a mad dog. The poisoning affects us all, us Ekdahls and everyone else. No one escapes". Although the Bishop represents the only evil that is foregrounded in Fanny and Alexander, Gustaf Adolf uses more general words, ones that have more to do with the beginning of the First World War, the period Bergman initially intended for the film, or, indeed, the Italian Fascist inter-war world surrounding Titta in Amarcord.[24] Bergman thus invents an individual adversary, the Bishop, who can be defeated - resisted, fooled, and eventually, magically killed - but motivates the populist conclusion, when Gustaf Adolf celebrates everyday hedonism in the domestic arena, by referring to more formidable foes. Gustaf Adolf's suggestion, "let us be happy while we are happy. Let us be kind, generous, affectionate and good. [...] It is necessary, not shameful, to take pleasure in the little world" is an attractive defense of a lifestyle refuting any political or ideological worries, a lifestyle vividly and appealingly illustrated by the happiness surrounding Gustaf Adolf at the festive Christening banquet table. As Egil Törnqvist points out, the little world he mentions refers not only to the theatre, the world of illusions which is so important to Fanny and Alexander, but also to the world of the children.[25] While Törnqvist looks upon this little world with optimism - seeing the children as representing the future and openness towards life and all life may offer - it is also possible to see it in Fellini's more pessimistic writing, cautioning against a society remaining at an adolescent stage, never maturing, never taking responsibility. Fellini finds that in such a society, whenever people get together they will only engage in nonsense, and whenever they are alone they are bewildered or "dreaming a ridiculous dream about the Orient, or Fred Astaire, or the myth about luxury and American splendor." [26] It seems that the Ekdahl family in the film is engaging in a similar myth. Writing about Bergman's reference to Henrik Ibsen's The Wild Duck (1884), Törnqvist reminds us that "like Ibsen's Ekdal family, Bergman's [Ekdahl family] need to retouch reality in order to be able to cope with it at all", preferring a world of illusions and life lies.[27] The little world put forward in Fanny and Alexander, the Ekdahl family or the provinciality of Uppsala, is thus very similar to Fellini's perception of Amarcord's Rimini as a "metaphor of an enclosure" with, in Bondanella's words, "an entire generation of Italians [...] enshrouded in a fog of ignorance”.[28]

In the end, this is where the films leave not only Alexander and the Ekdahl family or Titta and the Amarcordians, but also, I would

[24] I. Bergman, Images. My Life in Film, op. cit., p. 362 .

[25] E. Törnqvist, Filmdiktaren Ingmar Bergman, Arena, Malmö 1993, pp. 121-123.
[26] F. Fellini, "Il fascismo dentro di noi, Intervista di Valerio Riva," op. cit., p. 103. My translation. [27] E. Törnqvist, op. cit., p. 110. My translation. [28] P. Bondanella, op. cit., p. 129. 
suggest, the films' viewers. Within the mainly nostalgic evocations of the directors' childhood worlds, the painful power of authoritarian institutions - subjecting two ordinary persons to castor oil and carpet beating punishments - is momentarily exposed, before it is deconstructed and all but forgotten by both characters and viewers. The films' dialectics of foregrounding and conciliating disturbing episodes seem to have a parallel dialectic between authentic recollections of Bergman's and Fellini's childhood memories and the nostalgic desires of the audiences who so wholeheartedly embraced both Fanny and Alexander and Amarcord. Dark memories may be remembered, it seems, as long as they are allowed to be forgotten. 